\title{
Stereodivergent synthesis of two novel $\alpha$-aminophosphonic acids characterized by a cis-fused octahydroindole system
}

\author{
Alicia Arizpe ${ }^{[a]}$ Francisco J. Sayago,${ }^{[a]}$ Ana I. Jiménez, ${ }^{[a]}$ Mario Ordóñez, ${ }^{*[b]}$ and Carlos \\ Cativiela*,[a] $^{*}$
}

Keywords: Amino acids / Aminophosphonates / Phosphoproline analogues / Fused-ring systems / Diastereoselectivity

The synthesis of two new $\alpha$-aminophosphonic acids, namely $\left(2 S^{*}, 3 \mathrm{a} S^{*}, 7 \mathrm{a} S^{*}\right)-\quad$ and $\quad\left(2 R^{*}, 3 \mathrm{a} S^{*}, 7 \mathrm{a} S^{*}\right)$-octahydroindole-2phosphonic acids, is described. They are analogues of phosphoproline bearing a cyclohexane ring fused to the pyrrolidine moiety. The ring junction presents a cis stereochemistry in both cases, whereas the two compounds differ in the relative orientation of the cyclohexane and phosphonate moieties. The two amino acids have been prepared from a common starting material following stereodivergent routes that provide the desired stereoisomer with complete stereocontrol. The relative configuration of the compounds synthesised has been confirmed by $\mathrm{X}$-ray diffraction analysis. [a] Departamento de Química Orgánica, Instituto de Ciencia de Materiales de Aragón, Universidad de Zaragoza-CSIC, 50009 Zaragoza, Spain Fax: +34 976761210 E-mail: cativiela@unizar.es

[b] Centro de Investigaciones Químicas, Universidad Autónoma del Estado de Morelos, 62209 Cuernavaca, Mexico Fax: +527773297997

E-mail: palacios@ciq.uaem.mx

\section{Introduction}

$\alpha$-Aminophosphonic acids are surrogates of $\alpha$-amino acids in which the planar carboxylic acid $\left(\mathrm{CO}_{2} \mathrm{H}\right)$ has been replaced by a sterically more demanding tetrahedral phosphonic acid $\left[\mathrm{P}(\mathrm{O})(\mathrm{OH})_{2}\right]$. This replacement brings about important differences not only in molecular shape but also in acidity and other properties. $\alpha$-Aminophosphonic acids are currently attracting a great deal of interest in medicinal chemistry, as well as in agrochemistry, due to their outstanding biological and pharmacological properties. ${ }^{[1,2]}$ Thus, some of these compounds or their derivatives, including short peptides that incorporate them, find application as antibacterial, antiviral, and antifungal agents or as insecticides and herbicides. Others show promising anticancer activity or have proven effective in the treatment of osteoporosis.

The relevant properties exhibited by $\alpha$-aminophosphonic acids have stimulated the development of synthetic methods for these compounds. ${ }^{[1,2 \mathrm{a}, 3]}$ Much effort has been devoted in the last decades to the preparation of the phosphonic analogues of the 20 proteinogenic amino acids ${ }^{[4]}$ and, as a result, procedures for the synthesis of most of them are currently available. Once this goal was achieved, the present challenge faces the search for new structures, other than those analogous of the coded $\alpha$-amino acids. In this context, the wide variety of non-coded $\alpha$-amino acids synthesised in the last years by introduction of different types of modifications on the coded residues provides an invaluable source of inspiration. In particular, those non-proteinogenic $\alpha$-amino acids that have already shown exceptional properties are ideal candidates to serve as models for the construction of new $\alpha$-aminophosphonic acids.
Among such highly relevant non-coded $\alpha$-amino acids is octahydroindole-2-carboxylic acid (known in the abbreviated form as Oic, Figure 1). Oic is a proline analogue bearing a cyclohexane ring fused to the pyrrolidine cycle. Due to synthetic limitations, only the $(2 S, 3 \mathrm{a} S, 7 \mathrm{a} S)$ stereoisomer, characterized by a cis ring fusion and usually referred to as L-Oic (Figure 1), has been profusely investigated. This amino acid has allowed the development of highly potent, long-lasting peptides or peptiderelated molecules that find application as antiinflammatory, antiallergic, and analgesic agents, in the treatment of neurodegenerative diseases, and in the prevention of cardiovascular disorders, among others. ${ }^{[5,6]}$ Some of these L-Oic-containing compounds are already commercial (as the dipeptide Perindopril, one of the top antihypertensive drugs in the market ${ }^{[6 \mathrm{~g}, \mathrm{i}]}$ ) while others have entered clinical evaluation. Synthetic methods for the preparation of the remaining Oic stereoisomers are currently available, with some of them having been developed in our laboratories. ${ }^{[5]}$ a)<smiles>O=C(O)C1C[C@@H]2CCCC[C@H]2N1</smiles>

Oic

b)<smiles>O=[PH](O)C1C[C@@H]2CCCC[C@H]2N1</smiles>

$\left(2 S^{\star}, 3 a S^{\star}, 7 a S^{\star}\right)$

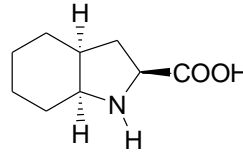

(2S,3aS,7aS)-Oic L-Oic<smiles>O=[PH](O)C1CC2CCCCC2N1</smiles>

$\left(2 R^{\star}, 3 \mathrm{a} S^{\star}, 7 \mathrm{a} S^{\star}\right)$
Figure 1. a) Structure of the proline analogue octahydroindole-2-carboxylic acid (Oic) (the positions of the chiral carbons are indicated). The most widely studied stereoisomer of Oic (L-Oic) is shown. b) Structure of the phosphonic surrogates of Oic whose synthesis is described in the present work.

The high value of L-Oic, together with our experience in the synthesis of different Oic stereoisomers and our interest in aminophosphonic acids, prompted us to undertake the preparation of two phosphonic surrogates of Oic, namely those exhibiting a cis ring junction and either a cis or a trans stereochemistry between 
the six-membered cycle and the phosphonic group, that is, $\left(2 R^{*}, 3 \mathrm{a} S^{*}, 7 \mathrm{a} S^{*}\right)-\quad$ and $\quad\left(2 S^{*}, 3 \mathrm{a} S^{*}, 7 \mathrm{a} S^{*}\right)$-octahydroindole-2phosphonic acids, respectively (Figure 1).

\section{Results and Discussion}

The target compounds differ in the stereochemistry at the $\alpha$ carbon while share a cis stereochemistry at the ring junction. Our experience $^{[5]}$ in the synthesis of Oic derivatives made us consider hydrogenation of an unsaturated precursor of the octahydroindole system as the most convenient transformation to ensure a cis ring fusion. On the other hand, we reasoned that a lactam system could provide the appropriate scaffold to create the desired $\alpha$ aminophosphonate functionality (Scheme 1). This consideration was based on two synthetic precedents described in the literature: a) the well-known reduction of the carbonyl group at the C5 position of $\mathrm{N}$-acyl pyroglutamic acid (5-oxoproline) derivatives to give the corresponding hemiaminal and further transformation into an aminal and then into an $\mathrm{N}$-acyliminium ion, which undergoes the addition of nucleophiles to provide access to 5-substituted prolines ${ }^{[7]}$ b) the reaction of trialkyl phosphites with $\mathrm{N}$ acyliminium ions derived from $\alpha$-methoxycarbamates, first reported by Shono. ${ }^{[8]}$

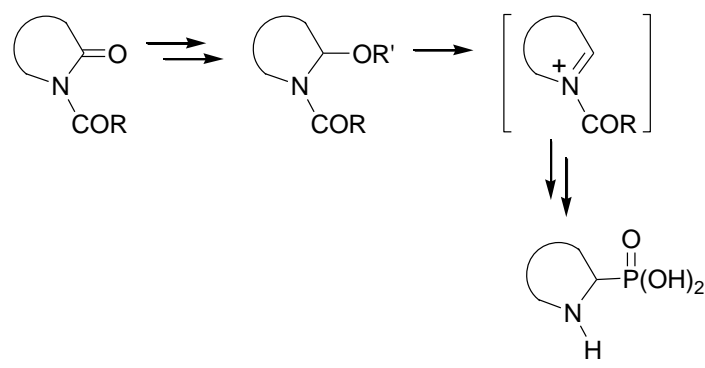

Scheme 1. Use of a lactam moiety as a precursor of an $\alpha$-aminophosphonic acid.

These considerations made us select commercially available 2indolinone (1, Scheme 2) as the starting material for the synthesis of the target compounds. This substrate bears a $\gamma$-lactam appropriate for the generation of the $\alpha$-aminophosphonate functionality. Simultaneously, it contains the desired bicyclic system exhibiting a double bond at the ring junction, which ensures a cis fusion upon hydrogenation. Most importantly, the sequence in which these key transformations are performed is crucial to define the stereochemistry of the final product, as explained in the following.

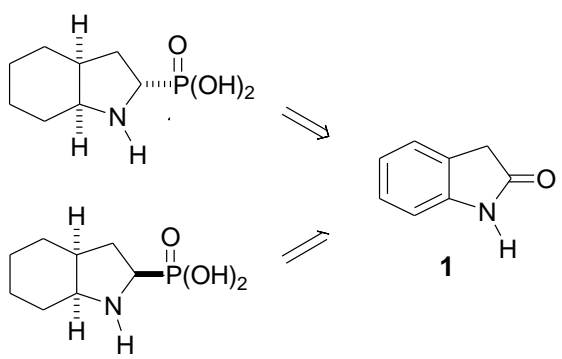

Scheme 2. Structure of 2-indolinone (also named 2-oxindole, 1), selected as a common precursor of the target aminophosphonic acids.

Firstly, we undertook the preparation of the derivative exhibiting a trans relative disposition between the phosphonic group and the six-membered cycle, that is, $\left(2 S^{*}, 3 \mathrm{a} S^{*}, 7 \mathrm{a} S^{*}\right)$-octahydroindole-2phosphonic acid. The first step in the synthesis involved hydrogenation of the aromatic ring in $\mathbf{1}$ (Scheme 3 ). The process was completed smoothly under an atmospheric pressure of hydrogen gas using platinum(IV) oxide as the catalyst and provided cis-octahydroindol-2-one (2) in quantitative yield. Such reaction conditions were selected on the basis of our previous experience in the preparation of Oic derivatives. We had observed ${ }^{[9]}$ that $\mathrm{PtO}_{2}$ allows the hydrogenation of indoline derivatives to proceed under mild reaction conditions whereas other catalytic systems based on palladium or rhodium have been reported $\mathrm{d}^{[5,10]}$ to require high pressures of hydrogen gas.

Compound 2 exhibits the desired cis stereochemistry at the ring junction and bears a $\gamma$-lactam functionality. Introduction of an acyl group on the nitrogen atom is a prerequisite for further transformation into an $\alpha$-aminophosphonate as outlined in Scheme 1. An acyl substituent of the carbamate type, namely the tertbutoxycarbonyl (Boc) group, was selected for this purpose since subsequent deprotection to generate the amino function can be accomplished under mild conditions. Treatment of 2 with di- tertbutyl dicarbonate $\left(\mathrm{Boc}_{2} \mathrm{O}\right)$ in the presence of a catalytic amount of 4-(dimethylamino)pyridine (DMAP) afforded the desired $N$-Boc protected derivative $\mathbf{3}$ in good yield (Scheme 3 ). This compound<smiles>O=C1Cc2ccccc2N1</smiles>

1

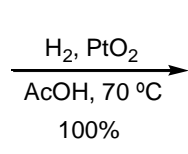

$00 \%$

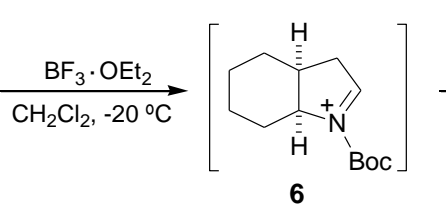<smiles>O=C1C[C@H]2CCCC[C@H]2N1</smiles>

2

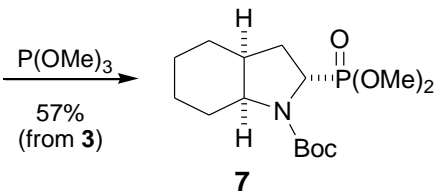

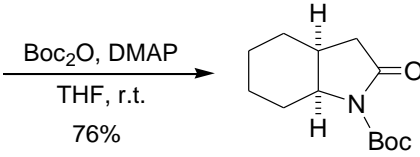

3

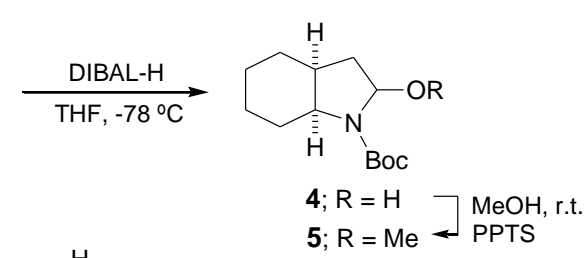<smiles>COP(=O)(O)[C@H]1C[C@@H]2CCCC[C@H]2N1CCCCO</smiles>

Scheme 3. Synthesis of $\left(2 S^{*}, 3 \mathrm{a} S^{*}, 7 \mathrm{a} S^{*}\right)$-octahydroindole-2-phosphonic acid. 
was made react with di-iso-butylaluminum hydride (DIBAL-H) to yield the unstable hemiaminal $\mathbf{4}$, which was not isolated and was treated immediately with methanol and catalytic pyridinium $p$ toluenesulfonate (PPTS) to provide the methoxyaminal $\mathbf{5}$. Subsequent reaction with trimethyl phosphite in the presence of boron trifluoride etherate ${ }^{[8]}$ led to the formation of 7 via the intermediate $N$-acyliminium 6. Notably enough, the desired dimethyl $N$-Boc-octahydroindole-2-phosphonate (7) was obtained as a single stereoisomer, with no trace of the epimer at the $\alpha$ carbon being detected by either ${ }^{1} \mathrm{H}$ or ${ }^{31} \mathrm{P}$ NMR analysis of the crude product. The isolated compound presumably exhibits a $\left(2 S^{*}, 3 \mathrm{a} S^{*}, 7 \mathrm{a} S^{*}\right)$ relative configuration since the nucleophilic attack of trimethyl phosphite on $\mathbf{6}$ most probably occurs from the less hindered face of the molecule, that is, opposite to the sixmembered cycle. X-ray diffraction analysis of single crystals of 7 (Figure 2) confirmed the expected $\left(2 S^{*}, 3 \mathrm{a} S^{*}, 7 \mathrm{a} S^{*}\right)$ stereochemistry, characterized by a trans arrangement of the cyclohexane and phosphonate moieties.

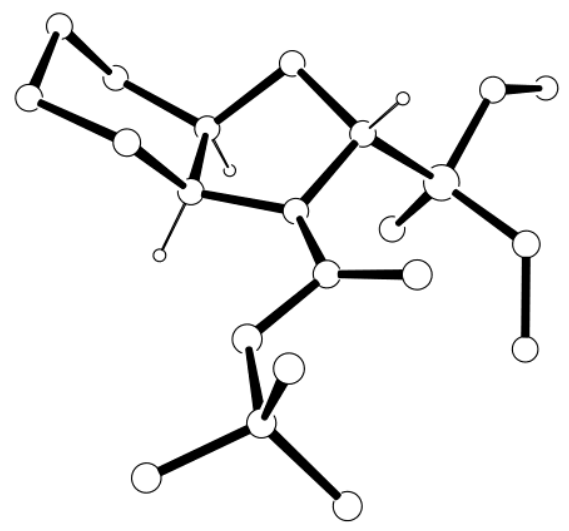

Figure 2. X-ray crystal structure of 7, exhibiting a $\left(2 S^{*}, 3 \mathrm{a} S^{*}, 7 \mathrm{a} S^{*}\right)$ relative stereochemistry (only one enantiomer is shown). All hydrogen atoms, except those attached to chiral carbons, have been omitted for clarity.

Removal of the protecting groups to obtain the free amino acid (8) was accomplished by treatment with a $33 \%$ solution of hydrogen bromide in acetic acid (Scheme 3). Additionally, selective deprotection of the amino function was attempted to generate the aminophosphonate $\mathbf{9}$, which may be of use for further derivatization. Unfortunately, the phosphonate ester proved not completely stable under the reaction conditions typically used to remove the Boc group. Thus, treatment of 7 with either a $3 \mathrm{~N}$ solution of hydrogen chloride in ethyl acetate or a 4:6 mixture of trifluoroacetic acid (TFA) and dichloromethane resulted in partial deprotection of the dimethyl phosphonate and, as a consequence, a mixture of products (including the ester, the hemiester and the free acid) was isolated. Selective cleavage of the $N$-Boc protecting group in $\mathbf{7}$ was finally achieved with a highly diluted solution of TFA in dichloromethane $(0.5 \mathrm{~N})$, as previously reported by Ricci et $a l{ }^{[11]}$ This procedure afforded the $\alpha$-aminophosphonate 9 in excellent yield (Scheme 3).

The synthesis of the epimeric derivative, $\left(2 R^{*}, 3 \mathrm{a} S^{*}, 7 \mathrm{a} S^{*}\right)$ octahydroindole-2-phosphonic acid, was next addressed. In this case, the introduction of the phosphonate group was envisaged prior to the reduction of the benzene ring to favour the desired cis relative disposition between the cyclohexane and phosphonate moieties. Accordingly, the first step in the route involved the introduction of a Boc protecting group in 2-indolinone (1). This process was not straightforward because of the nitrogen atom being flanked by an aromatic ring and a carbonyl group. As seen in Scheme 3 , the presence of a carbonyl moiety contiguous to the nitrogen atom in $\mathbf{2}$ does not hamper reaction with di-tert-butyl dicarbonate provided that catalytic DMAP is present. We have also observed $^{[12]}$ that the same conditions are effective for the $N$-Boc protection of the amino group in indoline-derived systems, where it is adjacent to a benzene ring. However, both situations coexist in 2indolinone (1), which presents, in addition, a highly reactive position towards electrophiles. It was, therefore, not unexpected that the conditions used for the $N$-Boc protection of 2 failed when applied to 1. No reaction was observed when tetrahydrofuran (THF) was used as a solvent, whereas acetonitrile afforded a complex mixture of compounds, including $\mathbf{1 0}$ and several products arising from the single or multiple acylation at the $1(\mathrm{~N}), 2(\mathrm{O}$ acylation), or 3 positions of the five-membered cycle. Similar products have been reported ${ }^{[13]}$ to be formed when triethylamine is added to the THF/DMAP system. Fortunately, the conditions developed for the carbamoylation of 2-indolinones based on the use of sodium carbonate in $\mathrm{THF}^{[14]}$ proved successful and allowed the isolation of $\mathbf{1 0}$ in good yield (Scheme 4).

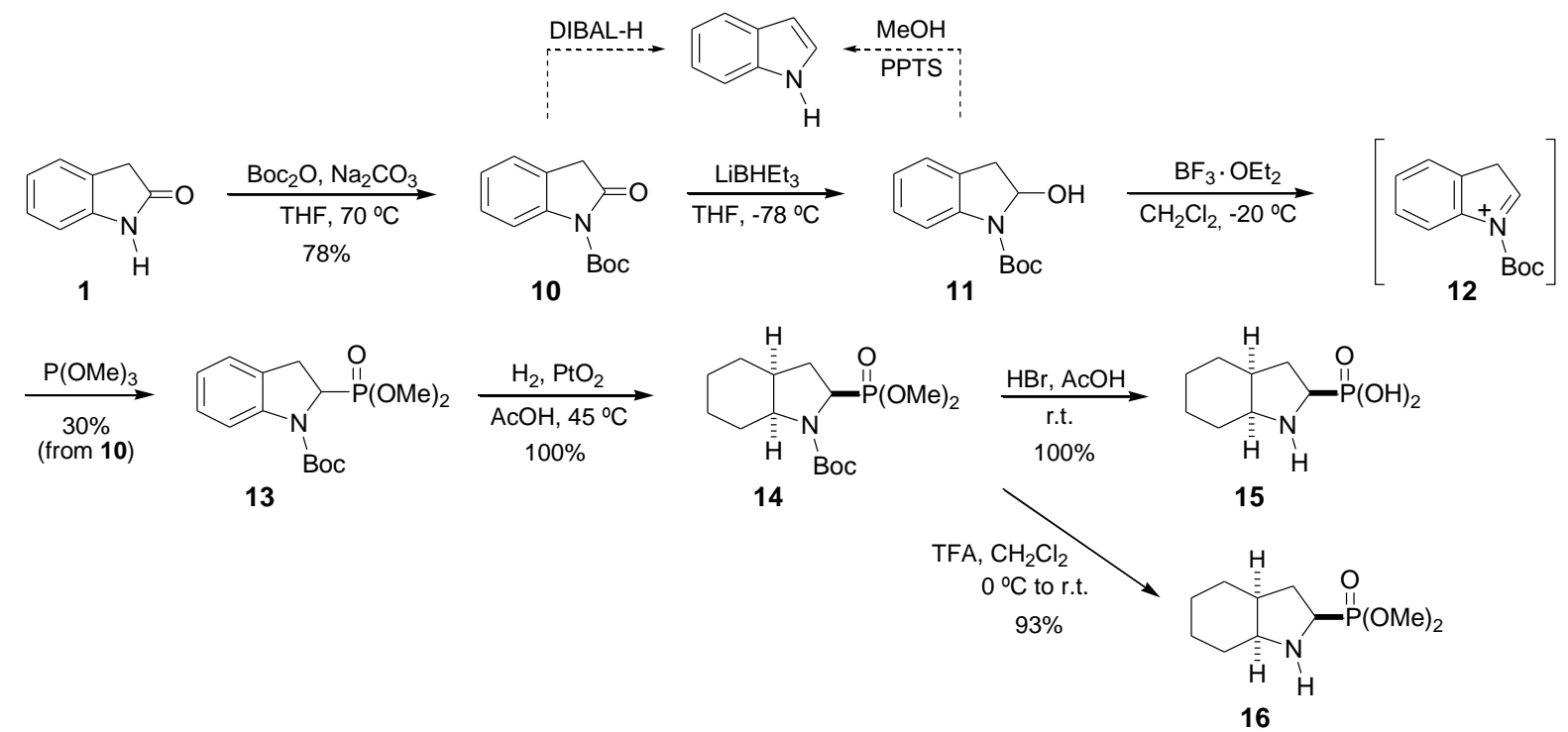

Scheme 4. Synthesis of $\left(2 R^{*}, 3 \mathrm{a} S^{*}, 7 \mathrm{a} S^{*}\right)$-octahydroindole-2-phosphonic acid. 
The introduction of a phosphonate group in $\mathbf{1 0}$ was next attempted via the formation of the intermediate hemiaminal, aminal, and iminium derivatives, as reported above for the trans compound (Scheme 3). However, in this case, reduction of $\mathbf{1 0}$ with DIBAL-H did not afford the expected hemiaminal 11 (Scheme 4). Instead, $\mathrm{N}$ Boc-indole was formed, presumably due to a straightforward aromatization of the reduced compound. In contrast, when lithium triethylborohydride (Super-Hydride ${ }^{\circledR}$ ) was used as the reducing agent, the desired hemiaminal (11) was obtained (Scheme 4). Difficulties were also encountered when this compound was made react with methanol to form the methoxyaminal. Again, $N$-Bocindole was isolated instead of the expected $O$-methylated product.

These difficulties prompted us to consider the direct transformation of the hemiaminal $\mathbf{1 1}$ into the iminium functionality without formation of the intermediate aminal derivative, as reported by some authors. ${ }^{[15]}$ On this basis, compound $\mathbf{1 1}$ was directly treated with boron trifluoride etherate and trimethyl phosphite to afford the $N$-Boc-indoline-2-phosphonate 13 (Scheme 4). Although a significant amount of $N$-Boc-indole was also formed in this process, the desired compound was isolated in $30 \%$ overall yield from $\mathbf{1 0}$.

The hydrogenation of the aromatic ring in $\mathbf{1 3}$ was carried out using $\mathrm{PtO}_{2}$ as a catalyst under the conditions commented above and afforded the octahydroindole derivative quantitatively. Notably enough, this hydrogenation process provided exclusively dimethyl $\left(2 R^{*}, 3 \mathrm{a} S^{*}, 7 \mathrm{a} S^{*}\right)$-octahydroindole-2-phosphonate (14), with no trace of the $\left(2 S^{*}, 3 \mathrm{a} S^{*}, 7 \mathrm{a} S^{*}\right)$ epimer $(7)$ being observed in the ${ }^{1} \mathrm{H}$ and ${ }^{31} \mathrm{P}$ NMR spectra. Hydrogenation of the benzene ring in $\mathbf{1 3}$ takes place from the less hindered face, i.e. that opposite to where the phosphonate group lies. As a consequence, the reduced system exhibits the cyclohexane moiety cis to the phosphonate substituent, as confirmed by X-ray diffraction analysis of $\mathbf{1 4}$ (Figure 3). The complete stereoselectivity of the process is highly remarkable and superior to that observed when the homologous carboxylic acid derivative was hydrogenated under similar conditions. ${ }^{[5,9]}$ In the latter case, a 90:10 mixture of epimers was obtained, with predominance of the cis derivative. The higher selectivity observed in the present work may be attributed to the larger steric hindrance associated to the dimethyl phosphonate group relative to the carboxylate moiety.

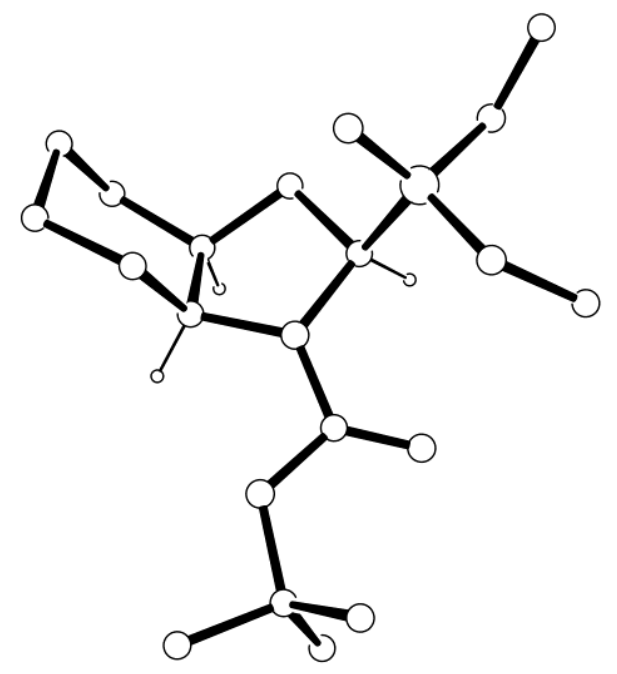

Figure 3. X-ray crystal structure of 14, exhibiting a $\left(2 R^{*}, 3 \mathrm{a} S^{*}, 7 \mathrm{a} S^{*}\right)$ relative stereochemistry (only one enantiomer is shown). All hydrogen atoms, except those attached to chiral carbons, have been omitted for clarity.
Finally, acidic treatment of $\mathbf{1 4}$ under similar conditions to those described for the trans derivative allowed the isolation of the dimethyl aminophosphonate $\mathbf{1 6}$ and the free amino acid $\mathbf{1 5}$ in excellent yields (Scheme 4).

\section{Conclusions}

Two stereoisomers of octahydroindole-2-phosphonic acid exhibiting a cis ring fusion and differing in the stereochemistry at the $\alpha$ carbon have been synthesised for the first time. The procedure relies on the use of a common, inexpensive, commercially available precursor, which is transformed into the desired compounds following stereodivergent routes. Full stereochemical control is achieved in both cases by efficiently combining the appropriate chemical transformations in the convenient order. Thus, when the hydrogenation step is performed before the introduction of the phosphonate group, only the compound exhibiting a trans relative disposition between the phosphonate and cyclohexane moieties is obtained. Conversely, when the phosphonate functionality is introduced prior to the hydrogenation of the aromatic ring, the cis stereoisomer is obtained exclusively. Therefore, a simple change in the order in which the two key reaction steps are carried out has allowed the simple and effective transformation of a common starting substrate into any of the target amino acids, with full stereochemical control. The compounds isolated are analogues of phosphoproline and may be of use in the development of biologically relevant materials.

\section{Experimental Section}

General: All reagents were used as received from commercial suppliers without further purification. Thin-layer chromatography (TLC) was performed on Macherey-Nagel Polygram ${ }^{\circledR}$ SIL G/UV 254 precoated silica gel polyester plates. The products were visualized by exposure to UV light $(254 \mathrm{~nm})$, iodine vapours or charring with cerium molybdate stain [aqueous solution of phosphomolybdic acid $(2 \%), \mathrm{CeSO}_{4} \cdot 4 \mathrm{H}_{2} \mathrm{O}(1 \%)$ and $\mathrm{H}_{2} \mathrm{SO}_{4}$ $(6 \%)$. Column chromatography was performed using $60 \mathrm{M}(0.04-0.063$ $\mathrm{mm}$ ) silica gel from Macherey-Nagel. Melting points were determined on a Gallenkamp apparatus. IR spectra were registered on a Nicolet Avatar 360 FTIR spectrophotometer; $v_{\max }$ is given for the main absorption bands. ${ }^{1} \mathrm{H}$, ${ }^{13} \mathrm{C}$ and ${ }^{31} \mathrm{P}$ NMR spectra were recorded on a Bruker AV-400 instrument at room temperature using the residual solvent signal as the internal standard; chemical shifts $(\delta)$ are expressed in parts per million and coupling constants $(J)$ in Hertz. High-resolution mass spectra were obtained on a Bruker Microtof-Q spectrometer.

X-ray structures: Single crystals of $\mathbf{7}$ and $\mathbf{1 4}$ were obtained by slow evaporation from dichloromethane/hexanes solutions. The X-ray diffraction data were collected at $150 \mathrm{~K}$ on an Oxford Diffraction Xcalibur diffractometer provided with a Sapphire CCD detector, using graphite monochromated Mo $K \alpha$ radiation $(\lambda=0.71073 \AA)$. The structures were solved by direct methods using SHELXS-97 ${ }^{[16 a]}$ and refinement was performed using SHELXL-97 ${ }^{[16 \mathrm{~b}]}$ by the full-matrix least-squares technique with anisotropic thermal factors for heavy atoms. Hydrogen atoms were located by calculation and affected by an isotropic thermal factor fixed to 1.2 times the $U_{\text {eq }}$ of the carrier atom (1.5 for the methyl protons). CCDC 812002 (7) and 812003 (14) contains the supplementary crystallographic data for this paper. These data can be obtained free of charge from The Cambridge Crystallographic Data Centre via www.ccdc.cam.ac.uk/data_request/cif.

Summary of crystallographic data for $7\left(\mathrm{C}_{15} \mathrm{H}_{28} \mathrm{NO}_{5} \mathrm{P}\right)$ : monoclinic, space group $P 2{ }_{1} / c ; a=16.0908(6) \AA, b=9.8211(4) \AA$, $c=11.1937(4) \AA$. $\beta=$ $91.996(3)^{\circ} ; Z=4 ; d_{\text {calcd }}=1.252$ g.cm ${ }^{-3} ; 16834$ reflections collected, 3129 unique $\left(R_{\mathrm{int}}=0.0838\right)$; data/parameters: $3129 / 201$; final $R$ indices $(I>2 \sigma I)$ : $R_{1}=0.058, w R_{2}=0.140$; final $R$ indices (all data): $R_{1}=0.111, w R_{2}=0.154$

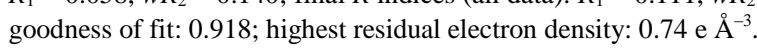


Summary of crystallographic data for $\mathbf{1 4}\left(\mathrm{C}_{15} \mathrm{H}_{28} \mathrm{NO}_{5} \mathrm{P}\right)$ : monoclinic, space group $P 2{ }_{1} / c ; a=15.9271(7) \AA, b=9.7690(5) \AA, c=11.4281(5) \AA, \beta=$

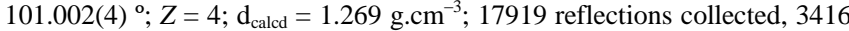
unique $\left(R_{\mathrm{int}}=0.037\right)$; data/parameters: $3416 / 201$; final $R$ indices $(I>2 \sigma I)$ : $R_{1}=0.033, w R_{2}=0.076$; final $R$ indices (all data): $R_{1}=0.052, w R_{2}=0.080$; goodness of fit: 0.968; highest residual electron density: $0.40 \mathrm{e} \AA^{-3}$.

cis-Octahydroindol-2-one (2): A mixture of 2-indolinone (1.00 g, 7.51 $\mathrm{mmol})$ and $\mathrm{PtO}_{2}(100 \mathrm{mg})$ in acetic acid $(50 \mathrm{~mL})$ was heated at $70{ }^{\circ} \mathrm{C}$ under an atmospheric pressure of hydrogen for $48 \mathrm{~h}$. Filtration of the catalyst and evaporation of the solvent provided 2 as a colourless oil $(1.04 \mathrm{~g}, 7.50 \mathrm{mmol}$, $100 \%$ yield). IR (neat): $v=1692 \mathrm{~cm}^{-1} .{ }^{1} \mathrm{H}$ NMR $\left(400 \mathrm{MHz}, \mathrm{CDCl}_{3}\right): \delta=$ 6.69 (bs, $1 \mathrm{H}, \mathrm{NH}), 3.65$ (q, $J=5.1 \mathrm{~Hz}, 1 \mathrm{H}, 7 \mathrm{a}-\mathrm{H}), 2.36-2.25(\mathrm{~m}, 2 \mathrm{H}, 3-\mathrm{H}$, $3 \mathrm{a}-\mathrm{H}), 2.05-1.95\left(\mathrm{~m}, 1 \mathrm{H}, 3-\mathrm{H}^{\prime}\right), 1.68-1.54\left(\mathrm{~m}, 3 \mathrm{H}\right.$, cyclohexane- $\left.\mathrm{CH}_{2}\right)$, $1.53-1.20\left(\mathrm{~m}, 5 \mathrm{H}\right.$, cyclohexane- $\left.\mathrm{CH}_{2}\right) \mathrm{ppm} .{ }^{13} \mathrm{C} \mathrm{NMR}\left(100 \mathrm{MHz}, \mathrm{CDCl}_{3}\right): \delta$ $=179.09(\mathrm{CO}), \quad 53.44 \quad(7 \mathrm{a}-\mathrm{C}), \quad 38.15 \quad(3-\mathrm{C}), \quad 34.44 \quad(3 \mathrm{a}-\mathrm{C}), 28.76$ (cyclohexane- $\mathrm{CH}_{2}$ ), 27.35 (cyclohexane- $\mathrm{CH}_{2}$ ), 22.80 (cyclohexane- $\mathrm{CH}_{2}$ ), 20.66 (cyclohexane- $\mathrm{CH}_{2}$ ) ppm. HRMS (ESI): calcd. for $\mathrm{C}_{8} \mathrm{H}_{13} \mathrm{NNaO}$ $[\mathrm{M}+\mathrm{Na}]^{+} 162.0889$; found 162.0886 .

cis- $\mathrm{N}$-(tert-Butoxycarbonyl)octahydroindol-2-one (3): A mixture of 2 (262 $\mathrm{mg}, 1.88 \mathrm{mmol}), 4$-(dimethylamino)pyridine $(23 \mathrm{mg}, 0.19 \mathrm{mmol})$, and di-tert-butyl dicarbonate $(1.03 \mathrm{~g}, 4.71 \mathrm{mmol})$ in THF $(15 \mathrm{~mL})$ was stirred at room temperature for $12 \mathrm{~h}$. Evaporation of the solvent followed by column chromatography (eluent: hexanes/ethyl acetate 4:1) afforded $\mathbf{3}$ as a white solid (344 mg, $1.44 \mathrm{mmol}, 76 \%$ yield). M.p. $61-63{ }^{\circ} \mathrm{C}$. IR $(\mathrm{KBr}): v=1785$, $1711 \mathrm{~cm}^{-1} .{ }^{1} \mathrm{H}$ NMR $\left(400 \mathrm{MHz}, \mathrm{CDCl}_{3}\right): \delta=4.01-3.94(\mathrm{~m}, 1 \mathrm{H}, 7 \mathrm{a}-\mathrm{H})$, 2.54-2.41 (m, 2H, 3-H, 3a-H), 2.31-2.25 (m, 1H, 3-H'), 2.22-2.14 (m, 1H, cyclohexane- $\left.\mathrm{CH}_{2}\right), 1.76-1.44\left(\mathrm{~m}, 4 \mathrm{H}\right.$, cyclohexane- $\left.\mathrm{CH}_{2}\right)$, overlapped with $1.50(\mathrm{~s}, 9 \mathrm{H}, t \mathrm{Bu}), 1.35-1.11\left(\mathrm{~m}, 3 \mathrm{H}\right.$, cyclohexane- $\left.\mathrm{CH}_{2}\right) \mathrm{ppm} .{ }^{13} \mathrm{C}$ NMR $\left(100 \mathrm{MHz}, \mathrm{CDCl}_{3}\right): \delta=174.31(\mathrm{CO}), 150.06(\mathrm{COO}), 82.59(t \mathrm{Bu}-\mathrm{C}), 57.82$ (7a-C), 35.77 (3-C), $31.64(3 \mathrm{a}-\mathrm{C}), 28.17\left(t \mathrm{Bu}-\mathrm{CH}_{3}\right), 28.15$ (cyclohexane$\left.\mathrm{CH}_{2}\right), \quad 25.94$ (cyclohexane- $\left.\mathrm{CH}_{2}\right), \quad 22.88$ (cyclohexane- $\left.\mathrm{CH}_{2}\right), \quad 20.37$ (cyclohexane- $\mathrm{CH}_{2}$ ) ppm. HRMS (ESI): calcd. for $\mathrm{C}_{13} \mathrm{H}_{21} \mathrm{NNaO}_{3}[\mathrm{M}+\mathrm{Na}]^{+}$ 262.1414; found 262.1418

Dimethyl $\quad\left(2 S^{*}, 3 \mathrm{a} S^{*}, 7 \mathrm{a} S^{*}\right)-N$-(tert-butoxycarbonyl)octahydroindole-2phosphonate (7): A $1 \mathrm{M}$ solution of di-iso-butylaluminum hydride in hexanes $(1.60 \mathrm{~mL}, 1.60 \mathrm{mmol})$ was slowly added to a solution of $\mathbf{3}(252 \mathrm{mg}$, $1.05 \mathrm{mmol})$ in anhydrous THF $(5 \mathrm{~mL}) \mathrm{kept}$ at $-78{ }^{\circ} \mathrm{C}$ under argon. After stirring at this temperature for $2 \mathrm{~h}$, the reaction was treated with saturated aqueous sodium acetate $(3 \mathrm{~mL})$ and allowed to warm to room temperature. A 3:1 mixture of diethyl ether and saturated aqueous ammonium chloride $(16 \mathrm{~mL})$ was then added and the resulting mixture was stirred at room temperature until a suspension was formed. The solid was filtered off under reduced pressure and washed with diethyl ether $(2 \times 10 \mathrm{~mL})$. The organic layer was separated and the aqueous phase was extracted with diethyl ether $(2 \times 20 \mathrm{~mL})$. The combined organic extracts were washed with water $(20$ $\mathrm{mL})$ and brine $(20 \mathrm{~mL})$, dried, filtered, and evaporated to provide the hemiaminal 4 as an oil. It was dissolved in methanol $(5 \mathrm{~mL})$ and treated with pyridinium $p$-toluenesulphonate $(26 \mathrm{mg}, 0.11 \mathrm{mmol})$. After stirring at room temperature for $2 \mathrm{~h}$, triethylamine $(48 \mathrm{mg}, 0.07 \mathrm{~mL}, 0.47 \mathrm{mmol})$ was added. The solvent was evaporated and the crude methoxyaminal 5 thus obtained was dissolved in anhydrous dichloromethane $(4 \mathrm{~mL})$ and kept under argon. Trimethyl phosphite $(131 \mathrm{mg}, 0.12 \mathrm{~mL}, 1.05 \mathrm{mmol})$ was added and the resulting solution was cooled to $-20{ }^{\circ} \mathrm{C}$. Boron trifluoride etherate $(149 \mathrm{mg}, 0.13 \mathrm{~mL}, 1.05 \mathrm{mmol})$ was added dropwise and the reaction mixture was slowly warmed to room temperature and stirred for 12 h. After quenching with water $(2 \mathrm{~mL})$, the two layers were separated and the aqueous phase was extracted with dichloromethane $(2 \times 5 \mathrm{~mL})$. The combined organic extracts were dried, filtered, and concentrated. Purification by column chromatography (eluent: ethyl acetate/hexanes $4: 1$ ) afforded 7 as a white solid (199 mg, $0.60 \mathrm{mmol}, 57 \%$ yield). M.p. $63-65^{\circ} \mathrm{C}$ IR (KBr): $v=1702,1244,1072,1038 \mathrm{~cm}^{-1} .{ }^{1} \mathrm{H}$ NMR $\left(400 \mathrm{MHz}, \mathrm{CDCl}_{3}\right): \delta$ $=($ duplicate signals are observed for some protons; asterisks indicate those corresponding to the minor rotamer) $4.21-4.14(\mathrm{~m}, 1 \mathrm{H}, 2-\mathrm{H}), 4.13 *-4.07 *$ $(\mathrm{m}, 1 \mathrm{H}, 2-\mathrm{H}), 3.73(\mathrm{~d}, J=10.5 \mathrm{~Hz}, 3 \mathrm{H}, \mathrm{OMe}), 3.72(\mathrm{~d}, J=10.5 \mathrm{~Hz}, 3 \mathrm{H}$, OMe), 3.70-3.62 (m, 1H, 7a-H), 2.77-2.66 (m, 1H, 3a-H), 2.61*-2.49* (m, $1 \mathrm{H}, 3 \mathrm{a}-\mathrm{H}), 2.41^{*}-2.31^{*}(\mathrm{~m}, 1 \mathrm{H}, 3-\mathrm{H}), 2.30-2.10(\mathrm{~m}, 2 \mathrm{H}, 3-\mathrm{H}), 2.05-1.95$ $\left(\mathrm{m}, 1 \mathrm{H}\right.$, cyclohexane- $\left.\mathrm{CH}_{2}\right), 1.74-1.53\left(\mathrm{~m}, 3 \mathrm{H}\right.$, cyclohexane- $\left.\mathrm{CH}_{2}\right), 1.49$ $1.39\left(\mathrm{~m}, 1 \mathrm{H}\right.$, cyclohexane- $\left.\mathrm{CH}_{2}\right)$ overlapped with $1.44(\mathrm{~s}, 9 \mathrm{H}, t \mathrm{Bu}), 1.28$ $0.92\left(\mathrm{~m}, 3 \mathrm{H}\right.$, cyclohexane- $\left.\mathrm{CH}_{2}\right)$ ppm. ${ }^{13} \mathrm{C}$ NMR $\left(100 \mathrm{MHz}, \mathrm{CDCl}_{3}\right): \delta=$ (duplicate signals are observed for most carbons; asterisks indicate those corresponding to the minor rotamer) $154.61(\mathrm{COO}), 80.07 *(t \mathrm{Bu}-\mathrm{C}), 79.75$
( $t \mathrm{Bu}-\mathrm{C}), 57.50$ (7a-C), $57.11 *$ (7a-C), $53.86 *(\mathrm{~d}, J=158.9 \mathrm{~Hz}, 2-\mathrm{C}), 53.43^{*}$ $(\mathrm{d}, J=7.0 \mathrm{~Hz}, \mathrm{OMe}), 52.79$ (d, $J=160.5 \mathrm{~Hz}, 2-\mathrm{C}), 52.61(\mathrm{~d}, J=7.1 \mathrm{~Hz}$,

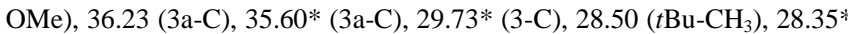
$\left(t \mathrm{Bu}-\mathrm{CH}_{3}\right), 27.81$ (3-C), 26.82* (cyclohexane- $\left.\mathrm{CH}_{2}\right), 26.01$ (cyclohexane$\mathrm{CH}_{2}$ ), 23.97 (cyclohexane- $\mathrm{CH}_{2}$ ), 23.58* (cyclohexane- $\left.\mathrm{CH}_{2}\right), 21.02 *$ (cyclohexane- $\mathrm{CH}_{2}$ ), 20.73 (cyclohexane- $\mathrm{CH}_{2}$ ) ppm. ${ }^{31} \mathrm{P}$ NMR $(162 \mathrm{MHz}$, $\mathrm{CDCl}_{3}$ ): $\delta=$ (a duplicate signal is observed; an asterisk indicates that corresponding to the minor rotamer) $28.52 *, 28.31 \mathrm{ppm}$. HRMS (ESI): calcd. for $\mathrm{C}_{15} \mathrm{H}_{28} \mathrm{NNaO}_{5} \mathrm{P}[\mathrm{M}+\mathrm{Na}]^{+}$356.1597; found 356.1619.

$\left(2 S^{*}, 3 \mathrm{a} S^{*}, 7 \mathrm{a} S^{*}\right)$-Octahydroindole-2-phosphonic acid hydrobromide (8): A 33\% solution of hydrogen bromide in acetic acid $(2 \mathrm{~mL})$ was added to $7(50 \mathrm{mg}, 0.15 \mathrm{mmol})$ and the reaction mixture was stirred at room temperature for $2 \mathrm{~h}$. The solvent was evaporated and the residue was taken up in water and lyophilised to afford $\mathbf{8}$ as a white solid $(43 \mathrm{mg}, 0.15 \mathrm{mmol}$ $100 \%$ yield). M.p. $262-264^{\circ} \mathrm{C}$ (dec.). $\mathrm{IR}(\mathrm{KBr}): v=3411,1153,1079 \mathrm{~cm}^{-1}$ ${ }^{1} \mathrm{H}$ NMR $\left(400 \mathrm{MHz}\right.$, DMSO- $\left.d_{6}\right): \delta=9.33-9.01\left(\mathrm{~m}, 2 \mathrm{H}, \mathrm{NH}_{2}\right), 4.66(\mathrm{bs}, 2 \mathrm{H}$, $\mathrm{OH}), 3.77-3.65(\mathrm{~m}, 1 \mathrm{H}, 2-\mathrm{H}), 3.54-3.45(\mathrm{~m}, 1 \mathrm{H}, 7 \mathrm{a}-\mathrm{H}), 2.31-2.21(\mathrm{~m}, 1 \mathrm{H}$ $3 \mathrm{a}-\mathrm{H}), 2.12-1.96(\mathrm{~m}, 2 \mathrm{H}, 3-\mathrm{H}), 1.74-1.42\left(\mathrm{~m}, 5 \mathrm{H}\right.$, cyclohexane- $\left.\mathrm{CH}_{2}\right)$ 1.39-1.18 (m, 3H, cyclohexane- $\left.\mathrm{CH}_{2}\right)$ ppm. ${ }^{13} \mathrm{C}$ NMR $(100 \mathrm{MHz}$, DMSO$\left.d_{6}\right): \delta=59.16(\mathrm{~d}, J=3.5 \mathrm{~Hz}, 7 \mathrm{a}-\mathrm{C}), 51.50(\mathrm{~d}, J=150.0 \mathrm{~Hz}, 2-\mathrm{C}), 36.43(\mathrm{~d}$ $J=4.9 \mathrm{~Hz}, 3 \mathrm{a}-\mathrm{C}), 29.87$ (3-C), 24.82 (cyclohexane- $\left.\mathrm{CH}_{2}\right), 23.58$ (cyclohexane- $\mathrm{CH}_{2}$ ), 21.36 (cyclohexane- $\left.\mathrm{CH}_{2}\right), 20.42$ (cyclohexane- $\mathrm{CH}_{2}$ ) ppm. ${ }^{31} \mathrm{P}$ NMR $\left(162 \mathrm{MHz}\right.$, DMSO- $\left.d_{6}\right): \delta=16.11 \mathrm{ppm}$. HRMS (ESI): calcd. for $\mathrm{C}_{8} \mathrm{H}_{17} \mathrm{NO}_{3} \mathrm{P}[\mathrm{M}-\mathrm{Br}]^{+}$206.0941; found 206.0944.

Dimethyl $\left(2 S^{*}, 3 \mathrm{a} S^{*}, 7 \mathrm{a} S^{*}\right)$-octahydroindole-2-phosphonate (9): An icecooled solution of $7(43 \mathrm{mg}, 0.13 \mathrm{mmol})$ in dichloromethane $(2.6 \mathrm{~mL})$ was treated with trifluoroacetic acid $(148 \mathrm{mg}, 0.10 \mathrm{~mL}, 1.30 \mathrm{mmol})$ and stirred at room temperature for $12 \mathrm{~h}$. The reaction mixture was diluted with dichloromethane $(10 \mathrm{~mL})$ and saturated aqueous sodium hydrogencarbonate $(5 \mathrm{~mL})$ was added. The layers were separated and the aqueous phase was further extracted with dichloromethane $(10 \mathrm{~mL})$. The combined organic layers were washed with brine $(10 \mathrm{~mL})$, dried, and filtered. Evaporation of the solvent afforded 9 as a white solid ( $28 \mathrm{mg}, 0.12 \mathrm{mmol}, 91 \%$ yield). M.p. $173-175{ }^{\circ} \mathrm{C}$ (dec.). IR (KBr): $v=3428,1236,1045 \mathrm{~cm}^{-1} .{ }^{1} \mathrm{H}$ NMR $(400$ $\left.\mathrm{MHz}, \mathrm{CDCl}_{3}\right): \delta=3.72(\mathrm{~d}, J=10.3 \mathrm{~Hz}, 3 \mathrm{H}, \mathrm{OMe}), 3.71(\mathrm{~d}, J=10.2 \mathrm{~Hz}, 3 \mathrm{H}$, OMe), 3.54 (ddd, $J=9.3,7.8,5.2,1 \mathrm{H}, 2-\mathrm{H}), 3.15-3.10(\mathrm{~m}, 1 \mathrm{H}, 7 \mathrm{a}-\mathrm{H}), 2.11$ (bs, 1H, NH), 2.03-1.91 (m, 2H, 3-H, 3a-H), 1.80-1.70 (m, 1H, 3-H'), 1.61-1.39 (m, 4H, cyclohexane- $\left.\mathrm{CH}_{2}\right), 1.33-1.25\left(\mathrm{~m}, 2 \mathrm{H}\right.$, cyclohexane- $\left.\mathrm{CH}_{2}\right)$, $1.20-1.07\left(\mathrm{~m}, 2 \mathrm{H}\right.$, cyclohexane- $\left.\mathrm{CH}_{2}\right)$ ppm. ${ }^{13} \mathrm{C}$ NMR $\left(100 \mathrm{MHz}, \mathrm{CDCl}_{3}\right): \delta$ $=57.55(\mathrm{~d}, J=6.3 \mathrm{~Hz}, 7 \mathrm{a}-\mathrm{C}), 53.11(\mathrm{~d}, J=7.1 \mathrm{~Hz}, \mathrm{OMe}), 52.98(\mathrm{~d}, J=7.3$ $\mathrm{Hz}, \mathrm{OMe}$ ), 51.31 (d, $J=168.4 \mathrm{~Hz}, 2-\mathrm{C}), 38.07$ (d, $J=4.6 \mathrm{~Hz}, 3 \mathrm{a}-\mathrm{C}), 32.22$ (3-C), 27.28 (cyclohexane- $\mathrm{CH}_{2}$ ), 26.65 (cyclohexane- $\mathrm{CH}_{2}$ ), 23.59 (cyclohexane- $\mathrm{CH}_{2}$ ), 20.95 (cyclohexane- $\mathrm{CH}_{2}$ ) ppm. ${ }^{31} \mathrm{P}$ NMR (162 MHz, $\mathrm{CDCl}_{3}$ ): $\delta=29.47 \mathrm{ppm}$. HRMS (ESI): calcd. for $\mathrm{C}_{10} \mathrm{H}_{21} \mathrm{NO}_{3} \mathrm{P}[\mathrm{M}+\mathrm{H}]^{+}$ 234.1254; found 234.1247

$\mathrm{N}$-(tert-Butoxycarbonyl)-2-indolinone (10): A mixture of 2-indolinone $(2.00 \mathrm{~g}, 15.04 \mathrm{mmol})$, di-tert-butyl dicarbonate $(8.20 \mathrm{~g}, 37.59 \mathrm{mmol})$, and sodium carbonate $(14.34 \mathrm{~g}, 135.32 \mathrm{mmol})$ in THF $(60 \mathrm{~mL})$ was heated at 70 ${ }^{\circ} \mathrm{C}$ for $12 \mathrm{~h}$. The solid was filtered off and the solvent was evaporated. Purification by column chromatography (eluent: hexanes/ethyl acetate $9: 1$ ) afforded $\mathbf{1 0}$ as a white solid (2.72 g, $11.66 \mathrm{mmol}, 78 \%$ yield). M.p. 63-66 ${ }^{\circ} \mathrm{C}$. IR (KBr): $v=1788,1720 \mathrm{~cm}^{-1} .{ }^{1} \mathrm{H}$ NMR $\left(400 \mathrm{MHz}, \mathrm{CDCl}_{3}\right): \delta=7.78$ (d, $J=7.8,1 \mathrm{H}, \mathrm{Ar}), 7.32-7.27(\mathrm{~m}, 1 \mathrm{H}, \mathrm{Ar}), 7.26-7.22(\mathrm{~m}, 1 \mathrm{H}, \mathrm{Ar}), 7.13(\mathrm{td}$, $J=7.8,1.0 \mathrm{~Hz}, 1 \mathrm{H}, \mathrm{Ar}), 3.65(\mathrm{~s}, 2 \mathrm{H}, 3-\mathrm{H}), 1.64(\mathrm{~s}, 9 \mathrm{H}, t \mathrm{Bu}) \mathrm{ppm} .{ }^{13} \mathrm{C}$ NMR $\left(100 \mathrm{MHz}, \mathrm{CDCl}_{3}\right): \delta=173.24(\mathrm{CO}), 149.31(\mathrm{COO}), 141.11(\mathrm{Ar})$ 128.19 (Ar), 124.33 (Ar), $124.32(\mathrm{Ar}), 123.34$ (Ar), 115.18 (Ar), 84.48 $(t \mathrm{Bu}-\mathrm{C}), 36.68(3-\mathrm{C}), 28.23\left(t \mathrm{Bu}-\mathrm{CH}_{3}\right)$ ppm. HRMS (ESI): calcd. for $\mathrm{C}_{13} \mathrm{H}_{15} \mathrm{NNaO}_{3}[\mathrm{M}+\mathrm{Na}]^{+}$256.0944; found 256.0948

Dimethyl $\quad N$-(tert-butoxycarbonyl)indoline-2-phosphonate (13): A solution of $10(2.61 \mathrm{~g}, 11.20 \mathrm{mmol})$ in anhydrous THF $(60 \mathrm{~mL})$ under argon was cooled to $-78^{\circ} \mathrm{C}$. A $1 \mathrm{M}$ solution of lithium triethylborohydride in THF $(16.80 \mathrm{~mL}, 16.80 \mathrm{mmol})$ was added dropwise and the reaction mixture was stirred at this temperature for $1 \mathrm{~h}$. It was treated with water $(10 \mathrm{~mL})$ and then allowed to warm to room temperature. Saturated aqueous sodium hydrogencarbonate $(25 \mathrm{~mL})$ was then added followed by $30 \%$ aqueous hydrogen peroxide $(10 \mathrm{~mL})$. The resulting mixture was stirred vigorously for $1 \mathrm{~h}$ and then extracted with ethyl acetate $(2 \times 20 \mathrm{~mL})$. The organic extracts were washed with water $(20 \mathrm{~mL})$ and brine $(20 \mathrm{~mL})$, dried, and filtered. Evaporation of the solvent afforded the hemiaminal $\mathbf{1 1}$ as a yellow oil. The crude product was dissolved in anhydrous dichloromethane (40 
$\mathrm{mL})$ and trimethyl phosphite $(1.39 \mathrm{~g}, 1.32 \mathrm{~mL}, 11.20 \mathrm{mmol})$ was added at room temperature under an argon atmosphere. The solution was cooled to $20{ }^{\circ} \mathrm{C}$ and boron trifluoride etherate $(1.59 \mathrm{~g}, 1.41 \mathrm{~mL}, 11.20 \mathrm{mmol})$ was added dropwise. The reaction mixture was slowly warmed to room temperature and stirred for $12 \mathrm{~h}$. After quenching with water $(10 \mathrm{~mL})$, the two layers were separated and the aqueous phase was extracted with dichloromethane $(2 \times 20 \mathrm{~mL})$. The combined organic extracts were dried, filtered, and concentrated. Purification by column chromatography (eluent: ethyl acetate/hexanes 4:1) gave $\mathbf{1 3}$ as an oil (1.09 g, $3.32 \mathrm{mmol}, 30 \%$ yield). IR (neat): $v=1702,1250,1060,1031 \mathrm{~cm}^{-1} .{ }^{1} \mathrm{H}$ NMR $(400 \mathrm{MHz}$, DMSO$\left.d_{6}\right): \delta=7.54$ (bs, $\left.1 \mathrm{H}, \mathrm{Ar}\right), 7.22(\mathrm{~d}, J=7.4 \mathrm{~Hz}, 1 \mathrm{H}, \mathrm{Ar}), 7.16(\mathrm{t}, J=7.7 \mathrm{~Hz}$, $1 \mathrm{H}, \mathrm{Ar}), 6.96$ (dt, $J=7.4,1.0 \mathrm{~Hz}, 1 \mathrm{H}, \mathrm{Ar}), 4.84$ (ddd, $J=11.2,4.3,2.3 \mathrm{~Hz}$, $1 \mathrm{H}, 2-\mathrm{H}), 3.61(\mathrm{~d}, J=10.5 \mathrm{~Hz}, 3 \mathrm{H}, \mathrm{OMe}), 3.57-3.45(\mathrm{~m}, 1 \mathrm{H}, 3-\mathrm{H})$ overlapped with 3.54 (d, $J=10.5 \mathrm{~Hz}, 3 \mathrm{H}, \mathrm{OMe}), 3.22-3.08$ (m, 1H, 3-H'), $1.52(\mathrm{~s}, 9 \mathrm{H}, t \mathrm{Bu}) \mathrm{ppm} .{ }^{13} \mathrm{C} \mathrm{NMR}\left(100 \mathrm{MHz}, \mathrm{DMSO}-d_{6}\right): \delta=151.38(\mathrm{COO})$, 141.72 (Ar), 130.45 (Ar), 127.20 (Ar), 124.58 (Ar), 122.90 (Ar), 115.24 (Ar), 81.08 ( $t \mathrm{Bu}-\mathrm{C}), 54.30(\mathrm{~d}, J=156.4 \mathrm{~Hz}, 2-\mathrm{C}), 52.89(\mathrm{~d}, J=6.9 \mathrm{~Hz}$, $\mathrm{OMe}), 52.74$ (d, $J=6.5 \mathrm{~Hz}, \mathrm{OMe}), 29.68(3-\mathrm{C}), 27.81\left(t \mathrm{Bu}^{\left.-\mathrm{CH}_{3}\right)} \mathrm{ppm} .{ }^{31} \mathrm{P}\right.$ NMR (162 MHz, DMSO- $\left.d_{6}\right): \delta=25.82 \mathrm{ppm}$. HRMS (ESI): calcd. for $\mathrm{C}_{15} \mathrm{H}_{22} \mathrm{NNaO}_{5} \mathrm{P}[\mathrm{M}+\mathrm{Na}]^{+}$350.1128; found 350.1123.

Dimethyl $\left(2 R^{*}, 3 \mathrm{a} S *, 7 \mathrm{a} S^{*}\right)-N$-(tert-butoxycarbonyl)octahydroindole-2phosphonate (14): A mixture of $13(206 \mathrm{mg}, 0.63 \mathrm{mmol})$ and $\mathrm{PtO}_{2}(21 \mathrm{mg})$ in acetic acid $(10 \mathrm{~mL})$ was heated at $45^{\circ} \mathrm{C}$ under an atmospheric pressure of hydrogen for $12 \mathrm{~h}$. Filtration of the catalyst and evaporation of the solvent afforded 14 as a white solid (209 mg, $0.63 \mathrm{mmol}, 100 \%$ yield). M.p. 72-74 ${ }^{\circ} \mathrm{C}$. IR (KBr): $v=1693,1230,1034 \mathrm{~cm}^{-1}$. ${ }^{1} \mathrm{H}$ NMR (400 MHz, DMSO- $d_{6}$ ): $\delta=4.08-4.01(\mathrm{~m}, 1 \mathrm{H}, 2-\mathrm{H}), 3.81-3.74(\mathrm{~m}, 1 \mathrm{H}, 7 \mathrm{a}-\mathrm{H}), 3.65(\mathrm{~d}, J=10.5 \mathrm{~Hz}$, $3 \mathrm{H}, \mathrm{OMe}), 3.64$ (d, $J=10.5 \mathrm{~Hz}, 3 \mathrm{H}, \mathrm{OMe}), 2.20-1.98$ (m, 3H, 3-H, 3a-H), $1.72-1.53\left(\mathrm{~m}, 4 \mathrm{H}\right.$, cyclohexane- $\left.\mathrm{CH}_{2}\right), 1.49-1.34\left(\mathrm{~m}, 2 \mathrm{H}\right.$, cyclohexane- $\left.\mathrm{CH}_{2}\right)$ overlapped with $1.40(\mathrm{~s}, 9 \mathrm{H}, t \mathrm{Bu}), 1.28-1.02\left(\mathrm{~m}, 2 \mathrm{H}\right.$, cyclohexane- $\left.\mathrm{CH}_{2}\right)$ ppm. ${ }^{13} \mathrm{C}$ NMR (100 MHz, DMSO- $\left.d_{6}\right): \delta=153.81$ (COO), $78.94(t \mathrm{Bu}-\mathrm{C})$, $58.35(7 \mathrm{a}-\mathrm{C}), 52.92(\mathrm{~d}, J=6.6 \mathrm{~Hz}, \mathrm{OMe}), 52.18(\mathrm{~d}, J=5.7 \mathrm{~Hz}, \mathrm{OMe})$ $52.00(\mathrm{~d}, J=163.9 \mathrm{~Hz}, 2-\mathrm{C}), 35.87$ (d, $J=5.9 \mathrm{~Hz}, 3 \mathrm{a}-\mathrm{C}), 29.00$ (3-C), $27.96\left(t \mathrm{Bu}-\mathrm{CH}_{3}\right), 27.32$ (cyclohexane- $\left.\mathrm{CH}_{2}\right), 25.19$ (cyclohexane- $\mathrm{CH}_{2}$ ), 23.55 (cyclohexane- $\mathrm{CH}_{2}$ ), 19.85 (cyclohexane- $\left.\mathrm{CH}_{2}\right)$ ppm. ${ }^{31} \mathrm{P}$ NMR (162 $\mathrm{MHz}, \mathrm{CDCl}_{3}$ ): $\delta=29.04$ ppm. HRMS (ESI): calcd. for $\mathrm{C}_{15} \mathrm{H}_{28} \mathrm{NNaO}_{5} \mathrm{P}$ $[\mathrm{M}+\mathrm{Na}]^{+}$356.1597; found 356.1599 .

$\left(2 R^{*}, 3 \mathrm{a} S^{*}, 7 \mathrm{a} S^{*}\right)$-Octahydroindole-2-phosphonic acid hydrobromide (15): A $33 \%$ solution of hydrogen bromide in acetic acid $(2 \mathrm{~mL})$ was added to $14(50 \mathrm{mg}, 0.15 \mathrm{mmol})$ and the reaction mixture was stirred at room temperature for $2 \mathrm{~h}$. The solvent was evaporated and the residue was taken up in water and lyophilised to afford $\mathbf{1 5}$ as a white solid $(43 \mathrm{mg}, 0.15 \mathrm{mmol}$ $100 \%$ yield). M.p. $138-140{ }^{\circ} \mathrm{C}$ (dec.). IR (KBr): $v=3413,1179,1024 \mathrm{~cm}^{-1}$. ${ }^{1} \mathrm{H}$ NMR (400 MHz, DMSO- $\left.d_{6}\right): \delta=9.62$ (bs, $\left.1 \mathrm{H}, \mathrm{NH}\right), 8.68(\mathrm{bs}, 1 \mathrm{H}, \mathrm{NH})$, 4.68 (bs, 2H, OH), 3.61-3.48 (m, 2H, 2-H, 7a-H), 2.32-2.22 (m, 1H, 3a-H), 2.14-2.03 (m, 1H, 3-H), 2.02-1.91 (m, 1H, 3-H'), 1.84-1.74 (m, 1H, cyclohexane- $\left.\mathrm{CH}_{2}\right), 1.72-1.46\left(\mathrm{~m}, 4 \mathrm{H}\right.$, cyclohexane- $\left.\mathrm{CH}_{2}\right), 1.41-1.16(\mathrm{~m}, 3 \mathrm{H}$ cyclohexane- $\left.\mathrm{CH}_{2}\right)$ ppm. ${ }^{13} \mathrm{C}$ NMR $\left(100 \mathrm{MHz}, \mathrm{DMSO}-d_{6}\right): \delta=58.62(7 \mathrm{a}-\mathrm{C})$, 53.07 (d, $J=147.8 \mathrm{~Hz}, 2-\mathrm{C}), 36.56$ (d, $J=8.2 \mathrm{~Hz}, 3 \mathrm{a}-\mathrm{C}), 28.73$ (3-C), 24.70 (cyclohexane- $\mathrm{CH}_{2}$ ), 24.25 (cyclohexane- $\mathrm{CH}_{2}$ ), 22.05 (cyclohexane$\mathrm{CH}_{2}$ ), 20.22 (cyclohexane- $\mathrm{CH}_{2}$ ) ppm. ${ }^{31} \mathrm{P}$ NMR (162 MHz, DMSO- $\left.d_{6}\right): \delta=$ 14.66 ppm. HRMS (ESI): calcd. for $\mathrm{C}_{8} \mathrm{H}_{17} \mathrm{NO}_{3} \mathrm{P}[\mathrm{M}-\mathrm{Br}]^{+}$206.0941; found 206.0936 .

Dimethyl (2R*,3a $\left.S^{*}, 7 \mathrm{a} S^{*}\right)$-octahydroindole-2-phosphonate (16). An icecooled solution of $\mathbf{1 4}(64 \mathrm{mg}, 0.19 \mathrm{mmol})$ in dichloromethane $(3.8 \mathrm{~mL})$ was treated with trifluoroacetic acid $(219 \mathrm{mg}, 0.15 \mathrm{~mL}, 1.92 \mathrm{mmol})$ and stirred at room temperature for $12 \mathrm{~h}$. The reaction mixture was diluted with dichloromethane $(15 \mathrm{~mL})$ and saturated aqueous $\mathrm{NaHCO}_{3}(8 \mathrm{~mL})$ was added. The layers were separated and the aqueous phase was further extracted with dichloromethane $(15 \mathrm{~mL})$. The combined organic layers were washed with brine $(10 \mathrm{~mL})$, dried, and filtered. Evaporation of the solvent provided 16 as a white solid (42 $\mathrm{mg}, 0.18 \mathrm{mmol}, 93 \%$ yield). M.p. $123-125^{\circ} \mathrm{C}$ (dec.). IR (KBr): $v=3391,1230,1198,1041 \mathrm{~cm}^{-1} .{ }^{1} \mathrm{H}$ NMR $\left(400 \mathrm{MHz}, \mathrm{CDCl}_{3}\right): \delta=3.79(\mathrm{~d}, J=10.3 \mathrm{~Hz}, 3 \mathrm{H}, \mathrm{OMe}), 3.77(\mathrm{~d}, J=10.4$ $\mathrm{Hz}, 3 \mathrm{H}, \mathrm{OMe}$ ), 3.41 (ddd, $J=9.2,8.4,5.7 \mathrm{~Hz}, 1 \mathrm{H}, 2-\mathrm{H}), 3.08-3.03(\mathrm{~m}, 1 \mathrm{H}$, 7a-H), 2.24 (bs, 1H, NH), 2.07-197 (m, 2H, 3-H, 3a-H), 1.83-1.71 (m, 1H, $\left.3-\mathrm{H}^{\prime}\right), \quad 1.68-1.55\left(\mathrm{~m}, \quad 2 \mathrm{H}, \quad\right.$ cyclohexane- $\left.\mathrm{CH}_{2}\right), \quad 1.53-1.42 \quad(\mathrm{~m}, 4 \mathrm{H}$, cyclohexane- $\left.\mathrm{CH}_{2}\right), 1.34-1.17\left(\mathrm{~m}, 2 \mathrm{H}\right.$, cyclohexane- $\left.\mathrm{CH}_{2}\right)$ ppm. ${ }^{13} \mathrm{C} \mathrm{NMR}$ $\left(100 \mathrm{MHz}, \mathrm{CDCl}_{3}\right): \delta=58.60(\mathrm{~d}, J=13.1 \mathrm{~Hz}, 7 \mathrm{a}-\mathrm{C}), 52.67(\mathrm{~d}, J=164.5 \mathrm{~Hz}$ 2-C), 53.41 (d, $J=6.8 \mathrm{~Hz}, \mathrm{OMe}), 52.98$ (d, $J=7.2 \mathrm{~Hz}, \mathrm{OMe}), 38.26$ (d, $J=$ $7.7 \mathrm{~Hz}, 3 \mathrm{a}-\mathrm{C}), 32.05$ (d, $J=1.9 \mathrm{~Hz}, 3-\mathrm{C}), 28.70$ (cyclohexane- $\mathrm{CH}_{2}$ ), 27.77 (cyclohexane- $\mathrm{CH}_{2}$ ), 23.68 (cyclohexane- $\left.\mathrm{CH}_{2}\right), 21.91$ (cyclohexane- $\mathrm{CH}_{2}$ ) ppm. ${ }^{31} \mathrm{P}$ NMR (162 MHz, $\mathrm{CDCl}_{3}$ ): $\delta=31.05$ ppm. HRMS (ESI): calcd. for $\mathrm{C}_{10} \mathrm{H}_{21} \mathrm{NO}_{3} \mathrm{P}[\mathrm{M}+\mathrm{H}]^{+}$234.1254; found 234.1253.

\section{Acknowledgments}

The authors thank the Ministerio de Ciencia e Innovación (project CTQ2010-17436), Consejo Superior de Investigaciones Científicas (project 2008MX0044; JAE-predoctoral fellowship to A.A.), Gobierno de Aragón (group E40), and Consejo Nacional de Ciencia y Tecnología (CONACYTMEXICO) (projects 62271 and J000.400/2009) for financial support.

[1] Aminophosphonic and Aminophosphinic Acids: Chemistry and Biological Activity (Eds.: V. P. Kukhar, H. R. Hudson), John Wiley \& Sons, Chichester, 2000.

[2] For recent reviews see: a) F. Orsini, G. Sello, M. Sisti, Curr. Med. Chem. 2010, 17, 264-289; b) E. D. Naydenova, P. T. Todorov, K. D. Troev, Amino Acids 2010, 38, 23-30; c) B. Lejczak, P. Kafarski, Top. Heterocycl. Chem. 2009, 20, 31-63.

[3] For recent reviews see: a) M. Ordóñez, H. Rojas-Cabrera, C. Cativiela, Tetrahedron 2009, 65, 17-49; b) K. Moonen, I. Laureyn C. V. Stevens, Chem. Rev. 2004, 104, 6177-6215.

[4] For a review see: M. Ordóñez, J. L. Viveros-Ceballos, C. Cativiela, A. Arizpe, Curr. Org. Synth., in press.

[5] F. J. Sayago, P. Laborda, M. I. Calaza, A. I. Jiménez, C. Cativiela, Eur. J. Org. Chem., 2011, in press (DOI: 10.1002/ejoc.201001710), and references therein.

[6] For some medicinally relevant compounds containing L-Oic see: a) J Lawandi, S. Gerber-Lemaire, L. Juillerat-Jeanneret, N. Moitessier, J. Med. Chem. 2010, 53, 3423-3438; b) K. Ersmark, J. R. Del Valle, S. Hanessian, Angew. Chem. Int. Ed. 2008, 47, 1202-1223; c) R. P. Hicks, J. B. Bhonsle, D. Venugopal, B. W. Koser, A. J. Magill, J. Med. Chem. 2007, 50, 3026-3036; d) J. M. Stewart, L. Gera, D. C. Chan, E. J. York, V. Simkeviciene, P. A. Bunn Jr., L. TarasevicieneStewart, Peptides 2005, 26, 1288-1291; e) J. M. Stewart, Peptides 2004, 25, 527-532; f) S. Reissmann, D. Imhof, Curr. Med. Chem. 2004, 11, 2823-2844; g) M. Hurst, B. Jarvis, Drugs 2001, 61, 867896; h) B. Portevin, M. Lonchampt, E. Canet, G. De Nanteuil, J Med. Chem. 1997, 40, 1906-1918; i) P. A. Todd, A. Fitton, Drugs 1991, 42, 90-114

[7] For reviews see: a) S. K. Panday, J. Prasad, D. K. Dikshit, Tetrahedron: Asymmetry 2009, 20, 1581-1632; b) C. Nájera, M. Yus, Tetrahedron: Asymmetry 1999, 10, 2245-2303.

[8] T. Shono, Y. Matsumura, K. Tsubata, Tetrahedron Lett. 1981, 22, 3249-3252.

[9] F. J. Sayago, A. I. Jiménez, C. Cativiela, Tetrahedron: Asymmetry 2007, 18, 2358-2364

[10] a) R. N. Kankan, D. R. Rao, PCT Int. Appl. WO 2005100317, 2005; b) M. Vincent, B. Marchand, G. Rémond, S. Jaguelin-Guinamant, G. Damien, B. Portevin, J.-Y. Baumal, J.-P. Volland, J.-P. Bouchet, P. H. Lambert, B. Serkiz, W. Luitjen, M. Laubie, P. Schiavi, Drug Des Discovery 1992, 9, 11-28; c) C. Pascard, J. Guilhem, M. Vincent, G Rémond, B. Portevin, M. Laubie, J. Med. Chem. 1991, 34, 663-669; d) M. Vincent, J. Baliarda, B. Marchand, G. Remond, U.S. Patent 4,914,214, 1990 .

[11] F. Fini, G. Micheletti, L. Bernardi, D. Pettersen, M. Fochi, A. Ricci, Chem. Commun. 2008, 4345-4347.

[12] F. J. Sayago, M. J. Pueyo, M. I. Calaza, A. I. Jiménez, C. Cativiela, Chirality, in press.

[13] M. Porcs-Makkay, G. Argay, A. Kálmán, G. Simig, Tetrahedron 2000, 56, 5893-5903.

[14] W. G. Rajeswaran, L. A. Cohen, Tetrahedron 1998, 54, 1137511380.

[15] See for example: a) R. A. Batey, D. B. MacKay, V. Santhakumar, J. Am. Chem. Soc. 1999, 121, 5075-5076; b) M. Kaname, H. Mashige, S. Yoshifuji, Chem. Pharm. Bull. 2001, 49, 531-536.

[16] a) G. M. Sheldrick, SHELXS-97, Program for the Solution of Crystal Structures; University of Göttingen: Göttingen, 1997; b) G. M. Sheldrick, SHELXL-97. Program for the Refinement of Crystal Structures; University of Göttingen: Göttingen, 1997. 
